\title{
Improving Awareness on Edible Insects through Dietary Education Based on Health Belief Model
}

\author{
Jung-Soon Han \\ Research Institute of Human Ecology, Korea University, Seoul, Korea
}

Corresponding author: Jung-Soon Han, Research Institute of Human Ecology, Korea University, 145 Anam-ro, Seongbukgu, Seoul 02841, Korea

Tel.: +82 232901672

Email: yohwa0960@korea.ac.kr

Received Augst 17, 2020

Revised November 26, 2020

Accepted December 07, 2020

Published December 30, 2020

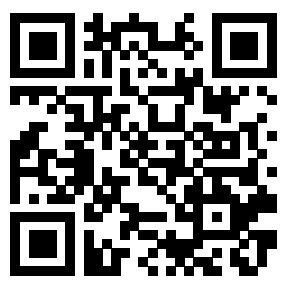

\begin{abstract}
Purpose: This study was conducted to find out the perceptions of edible insects among adults who have not consumed edible insects residing in Korea, and to evaluate the effects of improve awareness through education based on the health belief model. Methods: A survey was conducted with 182 adults aged 21-64 years who were living in Korea. Data analysis was performed using SPSS Statistics 24. Edible insect eating-related perception and experiences were analyzed using frequency analysis; and chi-square test. Results: In total, 127 (69.8\%, 53 men, women 74) responded that edible insects are emerging as a potential future food sources. The number of participants, being 151 who said that edible insects are likely to have high nutritional value is higher than those who said otherwise. There were 20 men and 51 women who do not consume edible insects due to the insects appearance. A total of 121 (65.9\%) participants repoted improved awareness after receiving education on edible insect and 112 (66.5\%) responded that it would have a positive effect on its consumption. Conclusion: Therefore, dietary education program to improve the awareness on edible insects is expected to greatly contribute to the future commercialization and industrialization of edible insect foods in the future.
\end{abstract}

Keywords: Edible insects, Dietary education, Health belief model, Improve awareness, Adult

\section{Introduction}

현재 세계 각국은 인구급증으로 인한 식량부족과 산업화로 각종 환경오염물질의 배출, 지구환경 변화에서 오는 온난화 등으로 식량 위기를 우려하고 있으며, 이에 국제연합 식량농업기구(FAO)에서 환 경오염의 저감화, 단백질 대체 식량자원으로 식용곤충을 선정하였 다(Alston et al., 2009; Hegsted et al., 1993). 식용곤충은 동물성 단백질의 주요 공급원인 가축에 비해 짧은 생애주기를 가지고 있어 공급이 용이하며(Chung et al., 2013), 적은 양의 사료와 물, 공간 이용으로 경제적 비용 절감 효과와 농약이나 항생제를 사용하지 않 고 온실가스를 적게 방출하므로 자연 환경을 훼손시키지 않아 생태 계를 보존하여 환경 오염을 줄일 수 있다는 장점이 있다(Arsenault $\&$ Brown, 2017). 식용곤충은 단백질 함량이 높고 불포화 지방산, 미량 무기질 등이 풍부할 뿐 아니라 항산화 영양소(Chong et al., 2017)와 여러 가지 생리기능 활성물질(Kim et al., 2020a; Na et al., 2016; No, 2010)을 많이 함유하고 있다. 이렇듯 많은 장점을 가지고 있는 식용곤충은 평균수명 증가로 고령인구가 늘어 노화로 인해 오는 노쇠와 기저질환이 있는 노인의 건강관리와 환자들의 단 백질 섭취 급원이나 과잉의 육류섭취로 인해 혈중 지질의 증가가 우려되는 사람들과 건강을 중요시하는 현대인들의 요구에 부합되 는 적합한 식량대체자원으로서(Hwang \& Choi, 2015; Kim et al., 2014) 활발히 연구가 진행되고 있다. 이러한 세계 흐름에 따라 국내 에서도 곤충산업 촉진을 위해 2016년 7종의 식용곤충이 식품원료 로서 사용 가능하게 되어(Jung et al., 2018) 식용곤충을 이용한 식 품소재나 식품, 화장품-의약품으로의 활용 등으로 적용분야가 다 양해지고 있어 식용곤충 시장 규모가 빠르게 성장할 것으로 예상되 고 있다. 그러나 아직까지 식용곤충의 외형에 대한 혐오감이나 인식 부족, 식용곤충에 대한 안전정보제공 부족, 정책 부족 등으로 친환 경적이며 영양가치가 높은 식용곤충이 대중화되거나 식품 등으로의 실용화가 이루어지고 있지는 않은 실정이다. 국내에서 이루어진 식 
용곤충 인식에 대한 연구도 대부분이 대학생을 대상으로 하거나 지 역이 지방으로 한정적인 경우가 많아 연구결과를 활용하기에는 한 계가 있다. 또한 아직까지 인식개선을 위한 교육이나 프로그램 등 의 실제적인 제안은 없는 실정이다. 이에 본 연구는 국내에 거주하 고 있는 식용곤충을 섭취해본 경험이 없는 성인(20세 이상-65세 미 만) 남녀를 대상으로 식용곤충에 대한 인식에 대해 알아보고, 이들 에게 건강신념모델에 근거한 식용곤충 인식 개선을 위한 식생활교 육을 한 후의 변화를 조사해 향후 식용곤충 인식개선을 위한 다양한 식생활교육 프로그램 개발이나 식용곤충 이용 식품 개발 등 여러 분 야에서 이용할 수 있는 기초자료로 활용하고자 한다.

\section{Methods}

\section{1.연구대상 및 자료수집}

대한민국에 거주하는 19 세 이상 65 세 미만의 식용곤충을 섭취해본 경험이 없는 성인을 대상으로, 식용 곤충 이용 식품의 이해도 및 섭취 실태에 대한 설문조사를 실시하였다. 본 연구는 대상자의 윤리적 측면 을 고려하여 $\mathrm{K}$ 대학 생명윤리심의위원회의 승인을 받아 수행되었다 (KUIRB. 201811), 모든 대상자에게 연구목적과 비밀유지, 자발적 참 여, 언제라도 철회 가능하며, 연구목적으로만 사용되는 것을 설명하였 다. 연구참여에 동의한 대상자에게만 설문지를 배포하고 지정 공간에

Table 1. General characteristics of the participants

\begin{tabular}{|c|c|c|c|c|}
\hline \multirow{2}{*}{ Variables } & \multirow{2}{*}{ Age } & \multicolumn{3}{|c|}{ Gender } \\
\hline & & Male N (\%) & Female N (\%) & Tatal N (\%) \\
\hline \multirow{6}{*}{ Age group } & $20-29$ & $44(46.3)$ & $51(53,7)$ & 95 (100.0) \\
\hline & $30-39$ & 26 (35.1) & 48 (64.9) & $74(100.0)$ \\
\hline & $40-49$ & $3(30.0)$ & $7(70.0)$ & $10(100.0)$ \\
\hline & $50-59$ & $1(100.0)$ & $0(0.0)$ & $1(100.0)$ \\
\hline & 60 over & $1(50.0)$ & $1(50.0)$ & $2(100.0)$ \\
\hline & Total (\%) & $75(41.2)$ & $107(58.8)$ & $182(100)$ \\
\hline \multirow{3}{*}{ Marital status } & Married & $32(52.5)$ & $29(47.5)$ & $61(100.0)$ \\
\hline & Unmarried & $43(41.2)$ & $78(64.5)$ & $121(100.0)$ \\
\hline & Total (\%) & $75(41.2)$ & $107(58.8)$ & $182(100.0)$ \\
\hline \multirow{6}{*}{ Family members } & 1 & $11(68.8)$ & $5(31.3)$ & $16(100.0)$ \\
\hline & 2 & 7 (38.9) & 11 (61.1) & $18(100.0)$ \\
\hline & 3 & $12(37.5)$ & $20(62.5)$ & $32(100.0)$ \\
\hline & 4 & $36(40.9)$ & $52(59.1)$ & 88 (100.0) \\
\hline & $>5$ & 9 (32.1) & $19(67,9)$ & $28(100.0)$ \\
\hline & Total (\%) & $75(41.2)$ & $107(58.8)$ & $182(100.0)$ \\
\hline \multirow{4}{*}{ Education } & High school or less & 5 (29.4) & $12(70.6)$ & $17(100.0)$ \\
\hline & Undergraduate (include attending) & $52(43.1)$ & $68(56.9)$ & $120(100.0)$ \\
\hline & Graduate school or more & $20(44.4)$ & $25(55.6)$ & $45(100.0)$ \\
\hline & Total (\%) & $77(42.3)$ & $105(57.7)$ & $182(100.0)$ \\
\hline \multirow{3}{*}{ Children } & No & $41(50.6)$ & $41(49.4)$ & $81(100.0)$ \\
\hline & Yes & 35 (34.3) & $66(65.7)$ & $99(100.0)$ \\
\hline & Total (\%) & $76(41.8)$ & $106(58.2)$ & $182(100.0)$ \\
\hline \multirow{6}{*}{ Residence } & Seoul & 27 (31.0) & $60(69.0)$ & $87(100.0)$ \\
\hline & Gyeonggi-do & $25(55.6)$ & $20(44.4)$ & $45(100.0$ \\
\hline & Metropolitan & $7(35.0)$ & $13(65.0)$ & $20(100.0)$ \\
\hline & District, Town, Subdivision & $13(59.1)$ & $9(40.9)$ & $22(100.0)$ \\
\hline & Others & $3(37.5)$ & $5(62.5)$ & $8(100.0)$ \\
\hline & Total (\%) & $75(41.2)$ & $107(58.8)$ & $182(100.0)$ \\
\hline \multirow{5}{*}{ Health consciousness } & Unconcerned & $3(75.0)$ & $1(25.0)$ & $4(100.0)$ \\
\hline & Consciousness & $12(54.5)$ & $10(45.5)$ & $22(100.0)$ \\
\hline & Concerned & $45(37.5)$ & $76(62.5)$ & $121(100.0)$ \\
\hline & More concerned & 15 (42.9) & $20(57.1)$ & 35 (100.0) \\
\hline & Total (\%) & 75 (41.4) & $107(58.6)$ & $182(100.0)$ \\
\hline
\end{tabular}


서 면담을 통해 설문지를 작성하고 대상자에게 소정의 선물을 제공하 였다. 자료수집 기간은 2019년 6월에서 8월까지 약 3개월간 진행되었 으며, 설문지는 총 200 부를 배포하였고 불충분한 자료 18 부를 제외한 182 부를 수거하여 자료분석에 이용하였다.

\section{2. 연구도구}

본 연구에 사용된 설문지는 전문가의 검토와 선행된 관련 연구 (Jung et al., 2018; Min et al., 2016)를 기초로 연구목적에 맞게 수정 보완하여 구성하였다. 설문지 구성은 표본의 일반적인 특성 9 문항, 식 용곤충에 대한 인식에 대한 5 문항, 식용곤충 인식개선 식생활교육프 로그램 개발에 대한 2 문항, 성별에 따른 식용곤충산업에 대한 전망에 대한 1 문항으로 구성되었다. 일반적 특성은 인구 통계학적 변인으로, 성별, 연령대, 혼인 여부, 직업, 가족 수, 최종 학력, 동거 자녀 유무, 그리고 거주지, 건강에 대한 관심도로 구성된 총 10 문항이었다. 성별 에 따른 식용 곤충에 대한 인식도 조사를 위한 설문내용은 식량자원으 로 식용 곤충이 대두되고 있다고 들어본 적이 있는가, 식약처에서 식 용 곤충으로 인정한 7개의 곤충에 대해 알고 있는가, 식용 곤충의 영 양가는 높을 것이라고 생각하는가, 식용 곤충이나 이용 식품을 섭취하 지 않는 이유에 대한 질문으로 구성되었다. 식용곤충을 섭취하지 않은 구체적 이유에 대한 질문으로는 외형이 불편해서, 섭취할 필요를 느끼 지 못해서, 가격이 적당하지 않아서, 위생문제가 걱정이 되어서 등으 로 구성하였다. 이를 조사 한 후 건강신념 모델(health belief model, $\mathrm{HBM})$ 을 참조하여 식용곤충에 대한 이해를 돕기 위한 교육을 실시한 후 식용곤충의 섭취 의향, 섭취한다면 식용 곤충 이용 식품의 형태 및 소비에 긍정적인 영향을 줄 것인가에 대해 등에 대해 조사하였다.

\section{3. 자료 분석}

설문을 통해 수집된 자료에 대한 통계분석은 SPSS Statistics
24.0 (SPSS Inc., USA)을 사용하였다. 대상자의 일반 사항에 대해서 는 빈도 분석(frequency analysis)과 교차분석을 실시하였으며 성별 에 따른 식용곤충 이용 식품에 대한 인식, 섭취하지 않은 이유, 향후 식용곤충 섭취의향과 섭취형태 식용곤충 인식개선 프로그램 교육 후 의 인식과 식용곤충 이용 식품 선택기준은 카이 제곱(Chi-square) 검정을 이용하였다 $(p<0.05)$

\section{Results and Discussion}

\section{1. 대상자의 인구통계학적 특성}

연구 대상자의 인구통계학적인 특성은 Table 1에 제시하였다. 전 체 조사 대상자는 남자는 75명(41.2\%) 여자는 107명(56.8\%)명이었 으며 20세 이상 65세 미만 성인을 연령별로 분류한 결과 20-29세 남자 44명(46.3\%), 여자 51명(53.7\%), 30-39세 남자 26명(35.1\%), 여자 48명(64.9\%), 40-49세 남자 3명, 여자 7명, 50-59세 남자 1 명, 60 세 이상 남자 1명, 여자 1명으로 19-39세가 대부분이었다. 혼 인 여부는 결혼이 남자 32 명(52.5\%), 여자 29명 (47.5\%), 비혼이 남 자 43 명(41.2\%), 여자 78명(64.\%)로 비혼이 결혼보다 높았고 특히 여자의 경우는 비혼이 결혼보다 2.5 배가 넘는 경향을 나타내었다. 이는 최근 사회적으로 결혼연령이 높아지고 여성의 사회진출이 적극 적으로 이루어지고 있는 것과도 무관하지 않다(Kang et al., 2012) 는 연구결과와도 비슷하였다. 가족 수는 4 인 이상 가족이 남자 36 명 (40.9\%), 여자 52명(59.1\%), 3인 가족이 남자 12 명, 여자 11 명으로 4 인 가족 형태가 많이 나타났다. 이는 충남대전지역 식용곤충 성인 의 식용곤충에 대한 인식조사에서 4 인 가족이 $52.5 \%$ 이었다는 연구 결과와 비슷한 경향을 나타냈다(Seo et al., 2018). 대상자들의 최종 학력은 대학(재학 중 포함) 졸업 이상이 남자 50명(43.1\%), 여자 66

Table 2. Awareness of edible insects by gender

\begin{tabular}{|c|c|c|c|c|c|}
\hline \multirow{2}{*}{ Variables } & & \multicolumn{2}{|c|}{ Gender } & \multirow{2}{*}{ Total N (\%) } & \multirow{2}{*}{$p$} \\
\hline & & Male N (\%) & Female N (\%) & & \\
\hline \multirow{2}{*}{ Are you aware of edible insects? } & Yes & $53(41.7)$ & $74(58.3)$ & $127(100)$ & \multirow[t]{2}{*}{$0.048^{*}$} \\
\hline & No & $22(40.0)$ & $33(60.0)$ & $55(100.0)$ & \\
\hline \multirow{5}{*}{$\begin{array}{l}\text { Where did you get information about } \\
\text { edible insects? }\end{array}$} & Online shopping & $33(43.8)$ & $41(56.3)$ & $74(100.0)$ & \multirow[t]{5}{*}{4.183} \\
\hline & Advertisement & $25(41.7)$ & $33(58.3)$ & $58(100.0)$ & \\
\hline & $\begin{array}{l}\text { Acquaintance or non-store } \\
\text { retailing }\end{array}$ & $8(22.2)$ & $18(77.8)$ & $22(100.0)$ & \\
\hline & $\begin{array}{l}\text { Department store, big retailer, } \\
\text { market, etc. }\end{array}$ & $4(0.0)$ & $6(100.0)$ & $10(100.0)$ & \\
\hline & Others & $8(36.4)$ & $10(63.6)$ & $18(100.0)$ & \\
\hline \multirow{2}{*}{$\begin{array}{l}\text { Are you aware of the } 7 \text { species of edible } \\
\text { insects authorized by the Korean Ministry } \\
\text { of Food and Drug Safety }\end{array}$} & Yes & $16(34.8)$ & $30(65.2)$ & $46(100.0)$ & \multirow[t]{2}{*}{1.049} \\
\hline & No & $59(43.4)$ & $77(56.6)$ & $136(100.0)$ & \\
\hline \multirow{2}{*}{ Do you think edible insects are nutritious? } & Yes & $61(40.1)$ & $90(59.9)$ & $151(100.0)$ & \multirow[t]{2}{*}{1.335} \\
\hline & No & $16(51.7)$ & 15 (48.3) & 31 (100.0) & \\
\hline
\end{tabular}

${ }^{*} p<0.05$ 
명 56.9\%로 대학이상 졸업자가 다수를 차지하였다. 동거 자녀가 있 는 사람은 남자 34 명 $(34.3 \%)$, 여자 65 명(65.7\%)로 자녀와 함께 동 거하는 경우가 더 많았다. 대상자들의 거주 지역은 남성은 수도권이 25 명(55.6\%), 여성 20명(44.4\%), 서울이 남자 27명(31\%), 여자 60 명 (69.0\%)로 남-여 모두 서울에 거주하는 경우가 더 많았고 남자 는 수도권 거주자가 많았다. 건강에 관심이 있는 정도는 '관심이 있 다'가 121 명 남자 45 명(37.5\%) 여자 76명(62.5\%)으로 여자가 더 많 은 관심을 나타내었다. '관심이 매우 많다' 는 남녀 총 35 명 중 여자 20 명(57.1\%), 남자 15 명(42.9\%)으로 나타나 대부분의 사람들이 건 강에 관심이 있는 것으로 나타났으며 여자가 남자보다 더 많은 관심 을 보였다(Table 1). 이는 성인기의 삶의 질은 건강이 가장 영향을 미친다는 연구와 같은 경향을 나타내었다(Kang et al., 2012).

\section{2. 성별에 따른 식용곤충의 식량자원으로서의 가치, 영양가에 대 한 인식}

성별에 따른 식용곤충의 식량자원으로서의 가치와 영양가에 대 한 인식은 Table 2 와 같다. 식량 자원으로 식용 곤충이 대두되고 있 다고 들어본 적이 있는지에 대해 묻는 질문에 '들어본 적이 있다' 라고 응답한 사람이 전체 127 명이었으며 남자는 53 명(41.7\%), 여 자는 74 명(58.3\%)으로 유의적으로 여자들이 더 많은 관심을 가지 고 있는 것으로 나타났다. '들어본 적이 없다'로 답한 55 명 중 남자 는 22 명, 여자는 33 명으로 대부분의 사람들이 식용 곤충에 대해 들 어본 적이 있는 것으로 나타났으며, 여자가 식용곤충에 대한 인식 도가 높았으며 이는 Seo et al. (2018)의 연구결과와 비슷한 경향 을 나타내었다. 식용곤충 구입은 온 라인 쇼핑몰이 74명(남자 33 명, 여자 41명)으로 가장 많았으며, 광고를 통해서 58명(남자 25명, 여자 33 명). 지인 등 비매장이 22 명(남자 8 명, 여자 18 명), 백화점 이나 마켓 10 명(남자 4 명, 여자 6 명), 기타 18 명(남자 8 명, 여자 10 명)으로 나타났다. 이는 다른 연구(Jung et al., 2018)에서 대형마 트를 선호한다는 결과와는 다른 경향을 나타내었다. 식품의약품안 전처에서 메뚜기, 누에번데기, 백강잠, 갈색저거리유충(고소애), 쌍 별귀뚜라미(쌍별이), 흰점박이꽃무지유충(꽃벵이), 장수풍뎅이유충 (장수애) 총 7 종을 식용곤충으로 인정하고 있다는 것을 알고 있는 지에 대해 묻는 질문에는 '알고 있다' 라고 대답한 사람이 46 명으로
이중 여자 30 명, 남자는 16 명으로 여자가 더 많이 알고 있는 것으 로 나타났다. '모른다'로 답한 사람은 136 명으로 더 많은 비율을 차 지하고 있었다. 식용 곤충의 영양가에 대해 묻는 질문에는 '영양가 가 높을 것 같다' 로 응답한 사람은 151 명으로 여자 90 명 (59.6\%), 남자 61명(40.4\%)로 여자가 영양가가 더 높을 것으로 생각하고 있 는 것으로 나타났으며, 그렇지 않을 것 같다는 총 31 명으로 적었으 며 남자는 16 명, 여자는 15 명으로 응답하여 성별 간에는 차이를 나 타내지 않았다(Table 2). 이는 식용곤충이 단백질 함량이 많은 영양 가 높을 것 같은 식품이라고 응답한 사람이 식용곤충 섭취 비경험자 의 $83.2 \%$ 라고 보고한 연구결과와 비슷한 경향을 보였다(Seo et al., 2018).

\section{3. 성별에 따른 식용곤충을 섭취하지 않는 이유}

성별에 따른 식용곤충을 섭취하지 않는 이유는 Table 3에 제시하 였다. 식용곤충을 섭취하지 않은 가장 큰 이유는 굳이 먹을 필요를 못 느껴서가 77 명으로 가장 많았으며 성별로는 남자 39명 여자 38 명으로 차이를 나타내지 않았다. 두 번째가 외형(색, 형태, 냄새, 식 감 등)이 불편해서가 71 명이었으며 남자는 20 명, 여자는 51 명으로 유의적으로 여자가 외형에 대해 불편함을 나타내었다. 다음으로 가 격이 만족스럽지 않아서 2 명, 위생이나 안전에 대한 확신이 없어서 13 명, 기타 18 명으로 나타나 여성들은 외형에 민감한 경향을 보여 다른 연구의 여성들이 식용곤충의 외형에 신경을 쓴다는 결과와 비 슷하였다(Kim et al., 2020b).

\section{4. 건강신념 모델에 근거한 식용곤충 인식개선 교육 후 식용곤충 에 대한 인식 변화}

건강신념 모델에 근거한 식용곤충에 대한 인식개선을 위한 교육 후 식용곤충에 대한 인식 변화에 대한 결과는 Table 4 에 제시하였 다. 영양교육과 식생활교육은 건강한 식생활을 실천하는데 필요한 지식(knowledge)을 바르게 이해하고 식생활을 실천하는 능력을 높 이고자 하는 태도(attitude)를 변화시키고 스스로 식생활에 대한 행 동(behavior)으로 옮겨 실천하게 하는 과정이다(Mo, 1990). 건강신 념모델은 1950 년대 후반 질병의 조기발견과 예방접종과 같은 예방 적 건강행동을 설명하기 위한 모델로 개발되었으며(Janz, 1984), 개

Table 3. Reasons for not taking edible insects before education to improve awareness of edible insects

\begin{tabular}{|c|c|c|c|c|c|c|}
\hline \multirow{2}{*}{ Variables } & & \multicolumn{2}{|c|}{ Gender } & \multirow{2}{*}{ Total N (\%) } & \multirow{2}{*}{$x^{2}$} & \multirow{2}{*}{$p$} \\
\hline & & Male N (\%) & Female N (\%) & & & \\
\hline \multirow{5}{*}{$\begin{array}{l}\text { Why did not you eat } \\
\text { edible insects? }\end{array}$} & $\begin{array}{l}\text { Not comfortable } \\
\text { with their appearance (color, types, } \\
\text { smell, etc.) }\end{array}$ & $20(28.1)$ & $51(71.8)$ & $71(100.0)$ & 11.207 & $p<0.05$ \\
\hline & No need to have edible insects & $39(50.6)$ & $38(49.4)$ & $77(100.0)$ & & \\
\hline & Not satisfied with price & $2(100.0)$ & $0(0.0)$ & $2(100.0)$ & & \\
\hline & $\begin{array}{l}\text { Not confident about sanitation, } \\
\text { safety, etc }\end{array}$ & $6(46.2)$ & $7(53.8)$ & $13(100.0)$ & & \\
\hline & Others & $8(44.4)$ & $10(55.6)$ & $18(100.0)$ & & \\
\hline
\end{tabular}


인의 건강신념과 건강행위 사이의 관련성을 설명하기 위해 건강관 련 분야에서 많이 활용되고 있다(Kim, 1997). 이러한 건강신념 모 델을 참조하여(Choi et al., 2016) 식용곤충에 대한 인식개선을 위 한 교육은 육류소비 증가로 인한 미래 단백질 식품 대체 소재로 대 두된 곤충의 식용 역사, 식용곤충의 종류, 영양가, 건강상의 이점(노 인이나 환자의 근감소 예방, 성장기 아동이나 청소년의 단백질 보 충 소재로서의 장점) 등에 대한 내용으로 이루어졌다. 식용곤충에 대한 이해를 높이기 위한 교육 후 식용곤충의 섭취의향과 섭취형태 등에 대해 조사한 결과 식용곤충을 기회가 되면 먹어보겠다로 응답 한 사람은 38 명으로 남자가 15 명, 여자는 23 명으로 유의적으로 여 성이 더 적극적으로 섭취의사를 밝혔다. 식용곤충 섭취에 대한 장점 을 알게 되면 먹어보겠다로 응답한 경우는 35 명으로 남자가 13 명, 여자는 22 명으로 같은 경향을 나타내었다. 앞으로도 굳이 먹을 필 요를 느낄 것 같지는 않다는 75 명으로 남자가 36 명, 여자는 39 명으 로 기회가 되면 먹어보겠다와 장점에 대해 알게 되면 먹어보겠다 로
답한 경우보다 많게 나왔으나 향후 식용곤충이 가진 장점에 대한 지 속적인 교육과 교육자료, 프로그램을 개발하고 계몽 홍보를 하게 되 면 개선의 여지가 있을 것으로 사료된다. 섭취하게 되면 섭취 형태 는 보충제로 답한 경우가 105 명으로 가장 많았으며 남녀 별로는 남 자 42 명(40.0\%), 여자 63명(60.0\%)으로 여자가 많이 섭취하겠다고 답하였다. 에너지 바나, 쿠키 등으로 섭취하겠다고 응답한 경우는 51 명으로 남자가 20 명, 여자는 32 명으로 여자가 더 긍정적인 반응 을 나타내었다. 앞으로 식용곤충 산업 발전에 대한 의견으로는 발전 할 것 같다가 83명으로 나타났으며 성별로는 남자가 37명(44.6\%), 여자 46명 $(55.4 \%)$ 으로 유의적인 차이를 나타내었다. 잘 모르겠다 고 대답한 경우도 85 명으로 남자 26 명, 여자 59 명으로 나타났다. 이 는 다른 연구결과와도 비슷한 경향을 나타내었다(Na et al., 2016; Chung et al., 2013). 이 같은 결과는 향후 식용곤충 인식개선을 위 한 다양한 프로그램이나 교육이 필요함을 시사하는 결과로 사료된 다.

Table 4. Attitude toward edible insects after education to improve awareness of edible insects

\begin{tabular}{|c|c|c|c|c|c|c|}
\hline \multirow{2}{*}{ Variables } & & \multicolumn{2}{|c|}{ Gender } & \multirow{2}{*}{ Total N (\%) } & \multirow{2}{*}{$x^{2}$} & \multirow{2}{*}{$p$} \\
\hline & & Male N (\%) & Female N (\%) & & & \\
\hline \multirow{4}{*}{$\begin{array}{l}\text { Will you have edible } \\
\text { insects in the future? }\end{array}$} & I am willing if I get a chance. & $15(39.4)$ & $23(60.5)$ & $38(100.0)$ & \multirow[t]{4}{*}{2.266} & \multirow[t]{4}{*}{$p<0.05$} \\
\hline & $\begin{array}{l}\text { I am willing if I acquire knowledge } \\
\text { about their benefits. }\end{array}$ & $13(37.1)$ & $22(62.9)$ & 35 (100.0) & & \\
\hline & I do not need to eat edible insects. & $36(48.0)$ & $39(52.0)$ & $75(100.0)$ & & \\
\hline & I will never eat edible insects. & $12(35.3)$ & $22(64.7)$ & $34(100.0)$ & & \\
\hline \multirow{6}{*}{$\begin{array}{l}\text { What type of edible } \\
\text { insect foods do you } \\
\text { prefer? }\end{array}$} & Snacks (cookies, bars, etc.) & $20(38.5)$ & $32(61.5)$ & $52(100.0)$ & \multirow[t]{6}{*}{10.658} & \\
\hline & Beverages & $6(100.0)$ & $\mathrm{O}(0.0)$ & $6(100.0)$ & & \\
\hline & Supplements & $42(40.0)$ & $63(60.0)$ & $105(100.0)$ & & \\
\hline & Instant foods & $2(40.0)$ & $3(60.0)$ & $5(100.0)$ & & \\
\hline & Raw (cleaned and prepared) & $0(0.0)$ & $2(100.0)$ & $2(100.0)$ & & \\
\hline & Others & $6(50.0)$ & $6(50.0)$ & $12(100.0)$ & & \\
\hline \multirow{3}{*}{$\begin{array}{l}\text { How do you view the } \\
\text { prospect of the edible } \\
\text { insect industry? }\end{array}$} & Seems to develop & $37(44.3)$ & $46(55.7)$ & $83(100.0)$ & \multirow[t]{3}{*}{19.624} & \multirow[t]{3}{*}{$p<0.05$} \\
\hline & It is unlikely to develop & $13(92.9)$ & $1(7.1)$ & $14(100.0)$ & & \\
\hline & I do not know & $26(30.6)$ & $59(69.4)$ & $85(100.0)$ & & \\
\hline
\end{tabular}

Table 5. Evalution of awareness after dietary education program of edible insect awareness improvement program

\begin{tabular}{|c|c|c|c|c|c|c|}
\hline \multirow{2}{*}{ Variables } & & \multicolumn{2}{|c|}{ Gender } & \multirow{2}{*}{ Total N (\%) } & \multirow{2}{*}{$x^{2}$} & \multirow{2}{*}{$p$} \\
\hline & & Male N (\%) & Female N (\%) & & & \\
\hline \multirow{3}{*}{$\begin{array}{l}\text { The awareness of edible } \\
\text { insects improved }\end{array}$} & Yes & $52(43.0)$ & $69(57.0)$ & $121(100.0)$ & \multirow[t]{3}{*}{11.29} & \\
\hline & No & $9(81.8)$ & $2(18.2)$ & $11(100.0)$ & & \\
\hline & I do not know & $14(28.0)$ & $36(72.0)$ & $50(100.0)$ & & \\
\hline \multirow{3}{*}{$\begin{array}{l}\text { It will be positive for } \\
\text { edible insect food } \\
\text { consumption }\end{array}$} & Yes & $51(45.5)$ & $61(54.5)$ & 112 (100.0) & \multirow[t]{3}{*}{12.824} & \multirow[t]{3}{*}{$p<0.05$} \\
\hline & No & $10(76.9)$ & $3(2.9)$ & $13(100.0)$ & & \\
\hline & I do not know & $15(26.3)$ & $42(73.7)$ & $57(100.0)$ & & \\
\hline \multirow{3}{*}{$\begin{array}{l}\text { Edible insects maybe } \\
\text { value as a substitute for } \\
\text { animal protein }\end{array}$} & Yes & 32 (37.6) & $53(62.4)$ & 85 (100.0) & \multirow[t]{3}{*}{7.218} & \multirow[t]{3}{*}{$p<0.05$} \\
\hline & No & $20(62.5)$ & $12(37.5)$ & 32 (100.0) & & \\
\hline & I do not know & $23(35.4)$ & 42 (64.6) & 65 (100.0) & & \\
\hline
\end{tabular}




\section{5. 식용곤충 인식개선 식생활교육 후 식용곤충 이용 식품 확산에 대한 견해}

식용곤충에 대한 인식개선을 위한 교육 후 인식개선, 식용곤충 이 용 식품소비 전망, 식용곤충충의 대체 단백질 식품 가능성에 대한 견해를 조사한 결과는 Table 5 와 같다. 식용 곤충 이해에 대한 교육 후 식용 곤충에 대한 인식에 긍정적인 영향을 줄 것인가에 대한 질 문에, 응답자의 대부분이(121명) '그렇다'라고 응답했다. 또한, 112 명이 식용 곤충의 소비에도 긍정적인 영향을 줄 것이라고 응답하여 유의적인 결과를 나타낸 것으로 보아 식용곤충 인식개선 식생활교 육은 필요하다고 사료된다. 또한 응답자 중 85명이 식용곤충은 동물 성 단백질 대체 식품으로 가치가 있을 것이라고 답하여 그렇지 않다 고 응답한 32 명보다 많아 유의적인 차이를 나타내었다. 이는 식용 곤충 산업 발전에 대한 전망이 긍정적일 수 있음을 예측되는 결과로 사료된다(Table 5). 또한 최 등(Choi et al., 2016)의 건강신념모델 에 근거한 식품안전·영양교육프로그램은 노인의 바람직한 식행동 을 유도하였다고 한 결과와 비슷한 경향을 나타내었다. 최근 대부분 의 사람들이 건강에 대해 많은 관심을 가지고 있고 육류 단백질 급 원의 부족, 환경 오염 등 여러 가지 문제로 인해 새로운 단백질 대체 급원으로 대두된 식용곤충은 운동선수를 위한 단백질 보충식품( $\mathrm{Min}$ et al., 2016), 노인과 환자를 위한 영양 보충식(Lee \& Kang, 2019; Kang et al., 2017; Kim et al., 2015) 등에 대한 연구가 일부 이루 어지고 있기는 하나 아직까지는 부정적인 인식이 강해 식용곤충 이 용이 활발하게 이루어지고 있지는 않은 실정이다. 향후 식용곤충에 대한 인식이 식생활교육에 의해 개선된다면 의약품과 기능성 화장 품의 신소재 원료 등으로 연구될 뿐 아니라 활용범위도 넓어질 것으 로 기대되며 실생활에서 건강지향식품으로 상용화 될 수 있는 가능 성을 시사하는 결과로 사료된다.

\section{Conclusion}

이상의 결과 식용 곤충이 식량자원으로 대두되고 있다고 응답한 사람이 127명(69.8\%)이었으며 남녀별로는 남자 53명, 여자는 73명 이 알고 있어 여자가 남자보다 많았으며 대부분의 사람들이 식용 곤 충의 식량자원으로서 대두되고 있다고 인지하고 있었다. 식약처에 서 식용으로 인정하는 식용곤충 7종의 인지여부는 47 명(34.40\%) 이 알고 있으며, 77 명 $(56.6 \%)$ 이 모른다고 대답하여, 식용곤충의 종 류에 대해서는 정확히 모르고 있는 사람이 횔씬 많았다. 식용 곤충 의 영양가는 '높을 것 같다' 147 명(80.8\%), 높지 않을 것 같다 29 명 (15.9\%)보다 훨씬 많았다. 식용 곤충이나 식용곤충 이용 식품을 섭 취하지 않는 이유는 외관이 불편해서라고 답한 경우가 남자 19명 (27.5\%), 여자 50명(72.5\%)으로 여성이 외형에 민감한 경향을 나 타내었다. 식용 곤충이나 식용곤충 이용 식품을 선택할 때 고려하
는 요인은 맛, 형태, 식 감 등 관능적인 면이 79 명(43.60\%)으로 가 장 많았다. 식용곤충에 대한 이해를 높이기 위한 교육 후 '식용 곤충 에 대한 인식을 개선시킬 것이다' 라고 응답한 사람이 120 명 $(65.9 \%)$ 이었고 성별로는 남자 52 명, 여자 68 명으로 여성이 더 긍정적이었 다. 식용곤충에 대한 인식을 개선시키기 위한 식생활 교육은 식용 곤충의 소비에도 긍정적인 영향을 줄 것이라고 응답한 사람이 110 명(60.4\%)으로 대부분이었으며 성별로는 남자 50명, 여자 60 명으로 여자들이 더 긍정적으로 답하였다. 식용 곤충산업 발전 가능성에 대 한 견해는 남자는 발전할 것 같다라고 응답한 사람이 79 명(44.4\%) 이었고, 성별로는 남자 35 명, 여자는 44 명으로 여성이 더 많았다. 이상의 결과 식용곤충에 대한 인식을 개선시키기 위한 교육이 향후 더 활성화되고 다양화 된다면 미래 식량자원이자 대체 단백질 공급 원으로 대두되고 있는 식용곤충과 식용곤충 이용 식품의 상용화와 산업화에 크게 기여할 것으로 기대되는 바이다.

\section{Acknowledgements}

This work was supported by the Ministry of Education of the Republic of Korea and the National Research Foundation of Korea (NRF-2018S1A5B5A07071965).

\section{Author's contribution}

JSH designed, performed study, analyzed statistics, interpreted data, and wrote the manuscript. All tables are created by the author.

\section{Author details}

Jung-Soon Han (Research Professor), Research Institute of Human Ecology, Korea University, 145 Anamro, Seongbuk-gu, Seoul 02841, Korea.

\section{References}

Alston JM, Beddow JM, Pardey PG. Agriculture. agricultural research, productivity, and food prices in the long run. Science, 325: 1209-1210, 2009.

Arsenault JE, Brown KH. Effects of protein or amino-acid supplementation on the physical growth of young children in low-income countries. Nutrition Reviews, 75: 699-717, 2017.

Choi JH, Lee ES, Lee YJ, Lee HS, Chang HJ, Lee KE, Yi NY, Ahn Y, Kwa TK. Food safety and nutrition education program for elderly and assessment of program effectiveness 
based on health belief model. Journal of Korean Society of Food Science and Nutrition, 45: 1366-1374, 2016.

Chong HS, Kim SY, Cho SR, Park HI, Baek JE, Kuk JS, Suh $\mathrm{HJ}$. Characteristics of quality and antioxidant activation of the cookies adding with Mealworm (Tenebrio molitor) and black bean powder. Journal of Food Hygiene and Safety, 32: 521-530, 2017.

Chung MY, Kwon EY, Hwang JS, Goo TW, Yun EY. Pretreatment conditions on the powder of Tenebrio molitor for using as a novel food ingredient. Journal of Sericulture Entomological Science, 51: 9-14, 2013.

Hegsted DM, Ausman LM, Johnson JA, Dallal GE. Dietary fat and serum lipids: an evaluation of the experimental data. The American Journal of Clinical Nutrition, 57: 875883, 1993.

Hwang SY, Choi SK. Quality characteristics of muffins containing Mealworm (Tenebrio molitor). Culinary Science \& Hospitality Research, 21: 104-115, 2015.

Janz NK, Becker MH. The health belief model: a decade later. Health Education Quarterly, 11: 1-47, 1984.

Kim $\mathrm{MH}$. Health belief model approach to health beliefs, attitude, and health behaviors concerning HIV/AIDS. Korean Journal of Health Education and Promotion, 14: 125-147, 1997.

Jung JH, Lim BK, Bae SJ. Study on consumers perception of edible insect foods. Journal of Korean Society of Food Culture, 33: 558-566, 2018.

Kang MS, Kim MJ, Han JS, Kim AJ. Fatty acid composition and anti-inflammatory effects of the freeze dried Tenebrio molitor Larva. The Korean Journal of Food and Nutrition, 30: 251-256, 2017.

Kang MK, Kim MS, Gang M, Oh K, Kwon JS, Lee SH. Factors affecting the mental health related quality of life in adults across the lifespan. Korean Journal of Rehabilitation Nursing, 15: 73-82, 2012.

Kim HM, Kim JN, Kim JS, Jeong MY, Yun EY, Hwang JS,
Kim AJ. Quality characteristics of patty prepared with mealworm powder. The Korean Journal of Food and Nutrition, 28: 813-820, 2015.

Kim SH, Kim KB, Noh JS, Yun EY, Choi SK. Quality characteristics of pasta with addition of mealworm (Tenebrio molitor). FoodService Industry Journal, 10: 5564, 2014.

Kim SH, Kim Y, Han JS. Antioxidant activities and nutritional components of cricket (Gryllus bimaculatus) powder and protein extract. Asian Journal of Beauty Cosmetology. 18: 163-172, 2020a.

Kim YJ, Kim Y, Han JS. Perception of edible insect foods among adults. Asian Journal of Beauty Cosmetology, 18: 53-63, 2020b.

Lee JT, Kang KO. A study on popularization and vitalization of edible insect by changing consumer perceptions and developing recipes: focus on college students in Seoul. Food Service Industry Journal, 15: 49-68, 2019.

Min KT, Kang MS, Kim MJ, Lee SH, Han JS, Kim AJ. Manufacture and quality evaluation of cookies prepared with Mealworm (Tenebrio molitor) powder. The Korean Journal of Food Nutrition, 29: 12-18, 2016.

Mo S. The present status and a future scheme in nutrition education. Journal of Nutrition and Health, 23: 208-212, 1990.

$\mathrm{Na}$ EJ, Jang HH, Kim GR. Review of recent studies and research analysis for anti-oxidant and anti-aging materials. Asian Journal of Beauty and Cosmetology, 14: 481-491, 2016.

No JK. A study of the sarcopenic obesity in aging. Asian Journal of Beauty and Cosmetology, 8: 139-148, 2010.

Seo JH, Park JY, Jeon MJ, Cho YI, Jeon MS. Perception and selection attributes of edible insects intake in adults in Daejeon and Chungnam are. Culinary Science \& Hospitality Research, 24: 170-182, 2018. 


\section{국문초록}

\section{건강신념 모델에 근거한 식용곤충 인식 개선 식생활교육의 효과}

한정순

고려대학교 생활과학연구소, 서울, 한국

목적: 본 연구는 국내에 거주하고 있는 식용곤충을 섭취해본 경험이 없는 성인의 식용곤충에 대한 인식을 알아보고, 이들에게 건강 신념모델에 근거한 식용곤충 인식개선 식생활교육을 한 후 효과를 평가하기 위해 수행되었다. 방법: 대한민국에 거주하는 20세 이 상 65세 미만 성인 182명을 대상으로, 설문조사를 통해 조사하였다. 자료 분석은 SPSS Statistics 24.0 통계 프로그램을 사용하였다. 대상자의 일반 사항과 식용 곤충에 대한 인식과 경험은 빈도 분석(frequency analysis)을 사용하였고, 교차분석(Cross Tabulation Analysis)과 카이 제곱(Chi-square) 검증을 사용하였다. 결과: 식용 곤충이 식량자원으로 대두되고 있다고 응답한 사람이 127 명 (69.8\%, 남자 53명, 여자는 74명)이었다. 식약처에서 식용으로 인정하는 식용곤충 7종의 인지여부는 46명(25.3\%, )이 알고 있으며, 136 명(74.7\%)이 모른다고 대답하였다. 식용 곤충의 영양가는 '높을 것 같다' 151 명(83.0\%), 높지 않을 것 같다 31명(17.0\%)보다 훨 씬 많았다. 식용 곤충이나 식용곤충 이용 식품을 섭취하지 않는 이유는 식용곤충의 외형이 불편해서 라고 답한 경우가 71 명(남자 20 명, $28.1 \%$, 여자 51명, $71.8 \%$ )으로 나타났다. 121 명(65.9\% 남자 52명, 여자 69명)이 식용곤충 인식개선 교육을 받은 후 식용 곤 충에 대한 인식이 개선되었다라고 응답하였다. 112 명(66.5\%, 남자 51 명, 여자 61 명)이 식용 곤충의 소비에도 긍정적인 영향을 줄 것이라고 응답하였다. 결론: 이상의 결과 식용곤충 인식개선을 위한 교육이 향후 더 활성화되고 다양화 된다면 미래 식량자원이자 대체 단백질 공급원으로 대두되고 있는 식용곤충과 식용곤충 이용 식품의 상용화와 산업화에 크게 기여할 것으로 기대되는 바이다.

핵심어: 식용곤충, 식생활교육, 건강신념모델, 인식개선, 성인

This work was supported by the Ministry of Education of the Republic of Korea and the National Research Foundation of Korea (NRF-2018S1A5B5A07071965).

\section{참고문헌}

강미경, 김명숙, 강문희, 오경옥, 권종선, 이선현. 성인의 생애주기별 정신건강 관련 삶의 질 영향요인. 재활간호학회지, 15: 73-82, 2012.

강미숙, 김민주, 한정순, 김애정. 동결건조 갈색거저리 유충의 지방산 조성과 항염증 효과. 한국식품영양학회지, 30 : 251-256, 2017.

김수희, 김기쁨, 노재승, 윤은영, 최수근. 갈색거저리를 첨가한 파스타의 품질특성. FoodService Industry Journal, 10: 55-64, 2014.

김시현, 김유경, 한정순. 쌍별귀뚜라미 분말과 분말 단백질 추출물의 영양성분과 항산화 활성. 아시안뷰티화장품학술지, 18: 163-172, 2020.

김윤정, 김유경, 한정순. 성인의 식용곤충과 식용곤충 식품에 대한 인식. 아시안뷰티화장품학술지, 18: 53-63, 2020. 김형미, 김정남, 김진수, 정미영, 윤은영, 황재삼, 김애정. 갈색거저리 유충 분말을 이용한 패티 제조 및 품질 특성. 한국식 품영양학회지, $28: 813-820,2015$.

김명혜. 건강신개념모델을 적용한 AIDS예방의 건강신념, 태도 및 건강행동. 보건교육건강증진학회지, $14: 125-147$, 1997.

나은주, 장현희, 김규리. 자연유래 항산화 원료와 제품개발을 위한 항산화 및 항노화 연구의 최신동향. 아시안뷰티화장품 학술지, 14: 481-491, 2016. 
노재경. 노화과정에서 저근육형 비만에 대한 이론적 연구. 아시안뷰티화장품학술지, 8: 139-148, 2010.

모수미. 우리나라 영양교육의 현황과 개선방안. Journal of Nutrition and Health, 23: 208-212, 1990.

민경태, 강미숙, 김민주, 이선희, 한정순, 김애정. 갈색거저리 유충 분말을 이용한 쿠키 제조 및 품질평가. 한국식품영양학 회지, 29: 12-18, 2016.

서지희, 박지연, 전민지, 조영인, 전미선. 대전 및 충남지역 성인의 식용곤충에 대한 인식 및 선택속성. Culinary Science \& Hospitality Research, 24: 170-182, 2018.

이진택, 강근육. 식용곤충에 대한 소비자들의 인식과 메뉴개발을 통한 대중화 활성화 방안 연구: 서울지역 대학생을 중심 으로. Food Service Industry Journal, 15: 49-68, 2019.

정미연, 권은영, 황재삼, 구태원, 윤은영. 갈색거저리의 식품 원료화를 위한 분말제조 조건 확립. 한국잠사곤충학회지, $51:$ 9-14, 2013.

정주희, 임배균, 배세정. 식용곤충식품에 대한 소비자 인식 연구. 한국식생활문화학회지, 33: 558-566, 2018.

정희선, 김수연, 조성륜, 박현일, 백지은, 국지수, 서희재. 식용 밀웜 분말(Tenebrio molitor)과 검은콩 분말을 첨가한 쿠 키의 품질특성 및 항산화 활성. 한국식품위생안전성학회지, 32: 521-530, 2017.

최정화, 이은실, 이윤진, 이혜상, 장혜자, 이경은, 이나영, 안윤, 곽동경. 건강신념모델에 근거한 노인대상 식품안전, 영양 교육 프로그램 효과 평가. 한국식품영양과학회지, 45: 1366-1374, 2016.

황수영, 최수근. 밀월(갈색거저리) 분말 첨가 머핀의 품질 특성. 한국조리학회지, 21: 104-115, 2015. 


\section{中文摘要}

\section{基于健康信念模型的饮食教育对食用昆虫的认识}

韓正順

高丽大学生活科学研究所, 首尔, 韩国

目的: 本研究旨在找出对未食用韩国食用昆虫的成年人中对食用昆虫的认识，并通过基于健康信念模型的教育评 估来提高认识的效果。方法: 对居住在韩国的182名21至64岁的成年人进行了调查。使用SPSS Statistics 24进行 数据分析。使用频率分析法分析与食用昆虫食相关的知觉和经验并使用交叉列表分析和卡方检验。结果：总共有 127例 $(69.8 \%$, 男53例, 女74例）回答说食用昆虫正在成为潜在的未来食物来源。可以说食用昆虫可能具有很 高的营养价值的151位参与者高于其他说法的参与者。由于昆虫的出现，不食用食用昆虫的有20名男性和51名 女性。共有121位 (65.9\%) 参与者在接受了有关食用昆虫的教育后，提高了认识，而112位参与者（66.5\%） 回答说, 这将对其食用产生积极影响。结论: 因此, 旨在提高人们对食用昆虫的认识的饮食教育计划有望为未来 食用昆虫食品的商业化和工业化做出巨大贡献。

关键词: 食用昆虫, 饮食教育, 健康信念模型, 提高认识, 成人 